\title{
The Historiography of Public Relations in Turkish Public Relations Books
}

\author{
Yrd. Doç. Dr. Halise KARAASLAN ŞANLI
}

ankara üniversitesi iletişim fakültesi halise.karaaslan@media.ankara.edu.tr

\begin{abstract}
Criticism on the hegemonic history of public relations (PR) paved the way for the emergence of new approaches to the historiography of $P R$. The most significant of such approaches is the exposure of genuine history of PR for each country, taking into account the specific socioeconomic and cultural context of each country. This study focuses on the handling of the history of PR in Turkish books on public relations published by prominent publishing houses in Turkey between 1967 and 2013. The study aims at presenting the general characteristics of historiography of $P R$ in Turkey as well as the new approaches that emerged through the end of 2000s. Data was obtained through literature survey and analyzed on a qualitative and quantitative basis using content analysis. According to the findings of the study, public relations history writing is observed as a newly developing area in Turkey. Studies including the PR history are concentrated on the American PR history and the Turkish PR history is either omitted or restricted to the developments after 1960s with the repetition of the pioneer studies.
\end{abstract}

keywords: public relations, public relations books, history of public relations in Turkey 


\section{Résumé}

\section{La rédaction de l'histoire des relations publiques dans les livres écrits en turc sur les relations publiques}

Les critiques envers le discours dominant sur l'histoire des relations publiques (RP) ont permis l'apparition de nouvelles tendances dans le domaine. L'une des plus importantes de ces tendances est l'effort de révéler des histoires en évaluant les pratiques des RP formées par le contexte socio-économique et culturel propre à chaque pays. L'objectif de cet article est l'analyse des livres sur les $R P$ rédigés en turc et publiés par des maisons d'édition réputées entre les années 1967 et 2013, afin de comprendre comment y est traitée l'histoire des $R P$. Notre recherche envisage de présenter aux lecteurs les traits généraux de la rédaction de l'histoire des RP en Turquie et les nouveaux développements survenus à la fin des années 2000. Le corpus est composé des livres choisis après un examen de la littérature existante, nous avons opté ensuite pour une analyse quantitatif et qualitatif de contenu. Selon les résultats de l'analyse, la rédaction de l'histoire des $R P$ en Turquie est un tout nouveau domaine. Les recherches consacrées à l'histoire des RP sont centrées surtout sur une histoire états-unienne, I'histoire des RP en Turquie étant soit négligée soit limitée aux développements vécus depuis 1960 et à la répétition des recherches pionnières.

mots-clés : relations publiques, livres sur les relations publiques, histoire des relations publiques en Turquie

\section{Özet}

\section{Türkçe Halkla İlişkiler Kitaplarında Halkla Illişkiler Tarihi}

Egemen halkla ilişkiler tarih anlatısına yönelik eleştiriler, halkla ilişkiler tarih yazımında yeni yönelimlerin açığa çıkmasına olanak sağlamıştır. Her ülkenin, kendine özgü sosyo-ekonomik, kültürel bağlamının oluşturduğu halkla ilişkiler uygulamalarını gözden geçirerek özgün halkla ilişkiler tarihleri açığa çıkarma çabası bu yönelimlerden en önemlisidir. Bu çalışmanın konusunu, 1967'den 2013 yılına kadar Türkçe yazılmış ve Türkiye'de tanınmış kitapevlerince basılmış halkla ilişkiler kitaplarında halkla ilişkiler tarihinin nasıl ele alındığının incelenmesi oluşturmaktadır. Çalışma, Türkiye halkla ilişkiler tarihi yazımının genel karakterini ve 2000'li yılların sonunda açığa çıkmış olan yeni gelişmeleri okuyucuya sunmayı amaçlamaktadır. Veriler literatür taraması sonucu elde edilerek nicel ve nitel içerik analizi yöntemi ile değerlendirilmiştir. Çalışmanın bulgularına göre, Türkiye'de halkla ilişkiler tarih yazımı yeni gelişen bir alan olarak karşımızda durmaktadır. Halkla ilişkiler tarihine yer veren çalışmalar genellikle $A B D$ halkla ilişkiler tarihi üzerine yoğunlaşmış, Türkiye halkla ilişkiler tarihi ya ihmal edilmiş ya da 1960 sonrası gelişmelerle ve öncü çalışmalarının tekrarıyla sınırlandırılmıştır.

anahtar kelimeler: halkla ilişkiler, halkla ilişkiler kitapları, Türkiye'de halkla ilişkiler tarihi 
"Public relations history is developing as an important area of scholarship within the academic discipline of public relations" (Pearson 1990: 27). Especially in the last decade, based on the fact that the history of public relations varies according to the cultural, economic and political context of each society, the public relations histories of different countries (such as Germany, the Netherlands, Spain, Japan, China, Iran, Israel, Palestine etc.) were made visible through presentations in international conferences (such as International History of Public Relations Conference, IHPRC, 2010 - 2014) and articles in the leading journals (such as Public Relations Review, Special Issue on Public Relations History 2013,2014) of the discipline. In addition to these, the number of studies on the history of public relations within the context of different countries in international literature increased by focusing on public relations through making use of new historical perspectives; also, new texts on comparative public relations took to the stage (such as Watson 2014).

When we analyze the specific case in Turkey, it may be stated that public relations history did not attract the required attention other than the limited number of exceptional studies, and the prevailing narrative which consists of a repetitive summary is still dominant. The studies focusing on the history of the development of public relations in Turkey are limited to a number of technical and scientific developments after the 1960s and practices in the private sector after the 1980s.

In other words, history of public relations in Turkey has not been analyzed with all its aspects taken into account and the practices specific to the conditions of the country have been jammed into the historical texts of other disciplines within the social sciences. This determination can be further explained through an example. In his book entitled Simgeden Millete II. Abdülhamid'den Mustafa Kemal'e Devlet ve Millet (From Symbol to Nation Abdulhamid II to Mustafa Kemal 2007), Selim Deringil, one of the prominent historians in Turkey, evaluates the last years of Ottoman Empire as follows: "One of the most important concerns of the Ottoman [Empire] was how it was 'regarded' among foreign countries. Ottoman Empire in the 19th century exhibited some clear examples of what we call public relations today" (34). This evaluation of Deringil made through an historical perspective is yet to be reflected in public relations research. One can add many other examples in a similar vein. These examples point out the importance and urgency of elaborating on the deficiencies and needs of historiography of public relations in Turkey. Research on the history of public relations in Turkey seem to be confined to a vicious cycle recently.

The main reason for this is the fact that it was only after the 1960s that public relations in Turkey was established as an academic discipline, included in the organization scheme of public institutions and developed within the private sector (Asna 1967; Mardin 1988; Peltekoğlu 1993; Asna 1997; Kazancı 2009; et al.). It is generally accepted that during the period between 1960 and 1980, 
public relations was handled in a "planned, systematic and defined" way and was established as a profession (Aktaş Yamanoğlu et al. 2013: 10).

Those analyzing the history of public relations based on a limited definition only focus on the history of public relations as a "profession". However, as one might observe, in recent years new developments have emerged in the history of public relations studies in Turkey. As it is going to be explained in greater detail in the discussion part, especially in the studies published in the past few years, the history of public relations specific to Turkey slowly began to be touched upon, whereas the field has been enriched with the introduction of new research subjects.

The objective of this study is to investigate the new developments focusing on the quality and features of the development of public relations beginning from the Ottoman Era through contemporary Turkey.

As stated above, a new interest in the historiography of public relations in the world has emerged. In order to contribute to this call from Turkey, the general profile of the history of public relations in Turkey must be unearthed. This study will attempt to shed light on the current understanding of the history of public relations in Turkey with a particular emphasis on current developments thereby contributing to the field by providing a solid ground for further research into the history of public relations.

The article will first present a summary of the general characteristics of historiography in the public relations books written in Turkey in Turkish; it will then explain the new developments regarding the historiography of public relations in Turkey along with suggestions and evaluations with regard to its further development.

\section{Method}

In order to define the general traits of the historiography of public relations in Turkey, to describe its characteristic features and to present the current developments in the study of public relations history in Turkey, books on public relations in Turkey have been surveyed first. The sample of the study consists of around 30 books (which are not collections or translations) written since 1967. Several factors gave way to such a selection: First of all, books used in the communication faculties of prominent universities in Turkey (Ankara University, Anadolu University, Ege University, Galatasaray University, Gazi University, Istanbul University, Marmara University, etc.) in the courses on public relations have been included in the study. Then, books reached through searching the Ankara University library with keywords 'public relations' have been analyzed within the scope of literature survey. 
Data obtained through literature survey was analyzed through qualitative and quantitative content analysis. Linguistic (words, concepts, names) and nonlinguistic (number of pages dedicated to a certain subject etc.) aspects have been chosen as the basis of content analysis which if frequently used in the analyses of documents and texts (books, especially course books, newspapers, documents, etc.)

The following questions were tried to be answered within the framework of the evaluation:

1. How many of the books on public relations in Turkey focus on the history of public relations?

2. Is there any specific heading in the contents part of the books on public relations in Turkey such as "the history of public relations" (or some other similar heading)? If yes, how many pages were allocated to this part?

3. Which countries' history of public relations is included in the books?

4. Is there any separate heading covering the history of public relations in Turkey in the books on public relations written in Turkey? If yes, how many pages were allocated to these parts?

5. When does the history of public relations in Turkey begin?

6. How many studies are there focusing on years before 1960 as part of the history of public relations?1

7. How many pages were allocated to the history of public relations before 1960 in these books?

The answers to these questions were presented in Table 3. However, the table only includes the books providing answers to the questions set out above, whereas the information on around 11 books $^{2}$ not including the history of public relations was not included in the table.

\section{Findings}

An important portion, in fact almost all, of the books on public relations in our country does not include any information on the history of public relations. These books only include information on the developments in United States of America in the way written in these books without any further comments on such books. To put it shortly, there are no studies in Turkey focusing on the

1 This question is particularly important. As stated above, according to the broadly accepted view, the history of public relations in Turkey is dated back to 1960s. In some studies reaching beyond this hegemonic narration, the history of public relations is dated back to before 1960 . Therefore, the answer to this question also reveals how much space was dedicated to the history of public relations in Turkey beyond the hegemonic narration.

2 Books which have been surveyed within the framework of the research but not included in the study as they contain no narration of the history of public relations are Arklan and Taşdemir (2010), Ataol (1991), Aydede (2004), Becerikli (2005, 2008), Berk (2007), Bilgin (2010), Durmaz (2000), Gültekin (2006), Oktay (2005). 
development of public relations in Turkey in association with the history of the country (Kazancı 2009: VI).

\section{The General Characteristics of the Historiography of Public Relations in Turkey and Criticism}

Only 19 out of 30 books written on the subject of public relations in Turkey since 1967 include a narration of the history of public relations. The history of public relations occupy around $15 \%$ of the books. The ratio of the history of public relations in Turkey, on the other hand, is $11 \%$, amounting to 604 pages.

Table 1: The distribution of the narration of public relations history in books on public relations in Turkey according to number of pages

\begin{tabular}{|l|l|l|l|}
\hline $\begin{array}{l}\text { Narration of the History of } \\
\text { Public Relations (Total) }\end{array}$ & $\begin{array}{l}\text { Narration of the History } \\
\text { of Public Relations in } \\
\text { Turkey }\end{array}$ & $\begin{array}{l}\text { Narration of the History of } \\
\text { Public Relations in Turkey } \\
\text { before 1960 }\end{array}$ & Total \\
\hline 859 & 604 & 114 & 5737 \\
\hline$\% 15$ & $\% 11$ & $\% 2$ & $\% 100$ \\
\hline
\end{tabular}

The central element of the history in Turkish PR books is the history of American public relations. Indeed, in almost all of the books, the American public relations history is explained, and then the history of public relations in Turkey is briefly touched upon, this being limited to a couple of pages. 357 of 604 pages in total dealing with the issue of historiography of public relations in Turkey, namely $60 \%$ of the total narration consists of two books. The autobiographical work of Asna (1997) and the book by Aktaş Yamanoğlu et al. (2014) dedicate a total of 357 pages to the history of public relations. In other words, the remaining 17 books dedicate a total of 247 pages to the history of public relations.

When it comes to the history of public relations in countries other than the USA, a single paragraph is included focusing on England (see Geçikli 2008). Countries other than the USA and England are either omitted from the narrative or simply referred to by including a list of their names (see Bülbül 2000; Çamdereli 2000). The typical tradition of referring to the European Countries is as follows: "Public Relations was established in France in 1946, in the Netherlands in 1948, in Norway in 1949 and in Belgium in the 1950s and this further develops the understanding of public relations to be imported from the USA" (Çamdereli 2000: 13). Such statements do not have further explanations.

The only study within literature in Turkish focusing on the public relations of countries other than the USA is the duplicate book consisting of the notes of the lecture delivered by Alâeddin Asna, who is regarded as the founder of public relations as a profession in Turkey, at the Faculty of Political Sciences, Vocational School of Press in 1967. There is a note reading "This book is the first 
study on public relations carried out by a Turk (p. 1)" in the book. The second part of the book focuses on the history of public relations. Between pages 17 and 34, entitled "The Story of a Long Life: History and Present Day", the history of public relations from the antique ages to the 20th century is presented. This book, which was used as a source book for many subsequent books, and in fact, even today, includes a separate part entitled "Public Relations in Five Continents" (1967: 25-34) where "the USA, England, Western Germany, France, Italy, Belgium, the Netherlands, Switzerland, Norway, Sweden, Spain, Japan, Australia, Latin America and other countries" are analyzed in detail. There are no other books focusing on the history of public relations in other countries among the books analyzed in this study. Asna's book (1967) is the first and only example in this regard. Another book written by Asna on the history of public relations in Turkey is entitled Public Relations... The Story of an Art-Profession: from past to present (1997) which consists of his memories. In these books, which increased the average number of pages (see Table 3), Asna explains the institutional development of public relations in Turkey together with his personal memoirs.

The general characteristics of historiography in PR books in Turkish are in line with the American sources, which determine the dominant historiography of PR books. Holism and linear chronology, which are defined as the general characteristics of American public relations historiography, are prevalent in Turkish books analyzed within the scope of this study. For instance, all of the books analyzed herein limit the history of public relations with the studies carried out by Ivy Lee and Edward L. Bernays, who are the founders of the profession of public relations.

Another feature of public relations books in Turkish is the fact that references remain the same. There are no new resources in addition to the studies carried out by the leading figures (Alâeddin Asna, Yücel Ertekin, M. Salim Kadibeşegil, Metin Kazanci, Betül Mardin, Nuri Tortop) in the field. Therefore, the historiography is often limited to the repetition of the information set out in the books written between the years 1967 and 1997.

Table 2: Reference books consulted in the historiography of public relations in Turkey and Frequency

\begin{tabular}{|l|l|l|l|l|l|l|}
\hline SOURCE & $\begin{array}{l}\text { Asna } \\
(1967,1974, \\
\text { 1997) }\end{array}$ & $\begin{array}{l}\text { Ertekin } \\
(1975, \\
\text { 1986, 1995) }\end{array}$ & $\begin{array}{l}\text { Kadıbeşegil } \\
(1986)\end{array}$ & $\begin{array}{l}\text { Kazancı } \\
(1980, \\
1986,1992, \\
\text { et al.) }\end{array}$ & $\begin{array}{l}\text { Mardin, } \\
\text { (1987) }\end{array}$ & $\begin{array}{l}\text { Tortop } \\
\text { (1973, } \\
1993)\end{array}$ \\
\hline $\begin{array}{l}\text { Frequency of } \\
\text { Reference }\end{array}$ & 6 & 5 & 4 & 6 & 5 & 4 \\
\hline
\end{tabular}


Another typical feature of public relations literature in Turkish is the progressive and evolutionary historiography just like American historiography. According to the progressive approach which is dominant in Western literature on the historiography of public relations, public relations is a discipline which continuously gets better and progresses (Lamme \& Russel 2010: 286). A similar approach is also prevalent in historiography in Turkey. According to this, modern and systematic public relations applications initiated in the 1960s continued their evolutionary development over the years as stated below and reached a modern state currently. The full chronological listing in the books is as follows:

1920: Anatolia Agency was established

1935: The $1^{\text {st }}$ Press Convention

1946: The program of Celal Bayar Government included a provision of Police Public Relations

1947: The program of Hasan Saka Government included a provision on "the necessity that the whole administrative and law enforcement agencies treat the people well".

1950s: The term "Public Relations" is used by Turkish Armed Forces.

1951: The program of the $2^{\text {nd }}$ Adnan Menderes Government included a sentence: "all administration is at the service of the public".

1961: "Press and Representation Agency" was established within the State Planning Organization

1962: Public relations were included in the Central Government Organization Research Project carried out by State Planning Organization and Turkey and Middle East Public Administration Institute.

1964: The first public relations campaign was prepared and carried out (campaign on encouraging the public for birth control).

1966: The department of Public Relations was established at Ankara University in the Faculty of Political Sciences Vocational School of Press - Public relations as an academic field of study.

1972: The first public relations association was established in Istanbul.

1973: The Institute of Journalism was transformed into a four-year vocational school. Its name was changed to Journalism and Public Relations.

1974: The first public relations company was founded.

1984: Public relations departments at the Ministries were changed into Consultancy of Press and Public Relations.

1996: The disciplinary regulation and professional principles regarding the regulation of the Public Relations Association were accepted (Geçikli 2008).

As shown in the table below, the information in this chronology on the years before 1960 is generally limited to 1-2 pages. Each development in the list set out above is explained in almost one sentence. The following example is the typical pattern of handling the public relations history before 1960: 
"The modern public relations in Turkey began with the establishment of Anatolia Agency in 1920 and the advertisement of the reforms by Atatürk. In the following stages, advertisement agencies, press office, information branch and press consultancy departments were established within the framework of the public institutions" (Geçikli 2008: 12).

The common feature of the books allocating relatively more space to the history of public relations before 1960, which is thought to be the beginning of the professionalization of public relations, is that they explain the history of public relations in a crude narrative deprived of historical in-depth analysis. An example of this is to refer to the Friday Greeting 3 in Ottoman Era, which is one of the important public relations rituals of the Ottoman Sultans, as "Fatih's interaction with the public on Fridays is a public relations activity" (Çamdereli 2000: 10). The books do not generally contain a contextualization of the social realities of the country while dealing with public relations.

The institutions established and the developments occurred after 1960, which is thought to be the beginning date for the development of public relations in Turkey, are briefly touched upon in these books by simply referring to names and dates without any detail. In other words, information on the history of the institutions, their public relations principles, people involved in these institutions, which are referred to as the fundamental aspects of public relations in the books, are not provided. The number of books providing detail on the establishment and development of such institutions is only limited to five, as can be seen in Table 3.

Another common feature of these books is that they mainly focus on professional practices rather than public communication in general. Especially the history of public relations after 1960 focuses on the development of the industry and the public relations practices, which inevitably leads to the omission of many concepts which are closely related to the public relations including publicity, public information, public education etc.

In summary, the general characteristics of the history of public relations in Turkish books are as follows:

- The history of public relations is not the main topic in the books. The history of public relations is only included in the books within the general introduction part which is more about the definition of public relations.

- Historiography of public relations in Turkish is limited to mainstream

3 Friday Greeting is one of the rituals bringing the Sultans together with the public in the Ottoman Era. This is a ceremony when the Sultan goes out of his palace to take part in the prayers at the mosque and after the prayer, the public hands in their complaints and requests to the agents of the Sultan. These rituals, which lasted from 1453 to the 1920s, are regarded as an important social event which enables the Sultans to come together with the public (Ipşirli 1991: 459-471). 
historiography. Ideological public relations activities, civil society and public relations, public relations activities conducted by organizations beyond the scope of private sector which reach beyond the mainstream narration are excluded from the scope of the historiography of public relations.

- The historiography of public relations in the books is limited to the repetition of leading books written in the 1970s and 1980s in Turkey.

- There is no periodical classification with regard to Turkey's history in the books 4 .

Table 3: Historiography of Public Relations in Public Relations Books in Turkish

\begin{tabular}{|c|c|c|c|c|c|c|c|c|c|}
\hline & 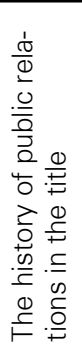 & 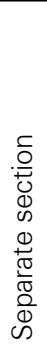 & 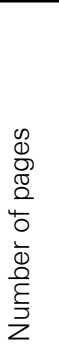 & 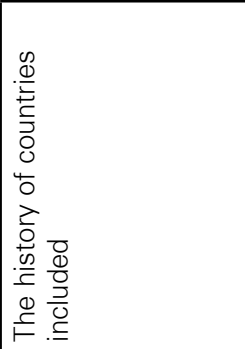 & 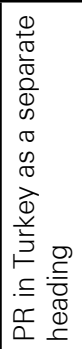 & 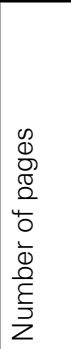 & 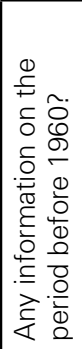 & 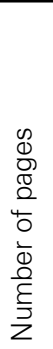 & 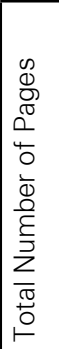 \\
\hline $\begin{array}{l}\text { Asna } 1967 \\
\text { (lecture notes) }\end{array}$ & $x$ & $x$ & 22 & $\begin{array}{l}\text { USA, England, } \\
\text { West Ger- } \\
\text { many, France, } \\
\text { Italy, Belgium, the } \\
\text { Netherlands, Swit- } \\
\text { zerland, Norway, } \\
\text { Sweden, Spain, } \\
\text { Japan, Australia, } \\
\text { Latin America }\end{array}$ & - & - & - & - & 218 \\
\hline Asna 1997 & $x$ & $x$ & 120 & Turkey & $x$ & 120 & - & - & 297 \\
\hline Tortop 1973 & $x$ & $x$ & 9 & $\begin{array}{l}\text { USA, France, Italy, } \\
\text { England }\end{array}$ & $x$ & 4 & $x$ & 2 & 230 \\
\hline Kadıbeşegil 1986 & $x$ & $x$ & 7 & USA, Turkey & & 3 & $x$ & 1 & 241 \\
\hline Ertekin 1995 & $x$ & - & 5 & USA & - & - & - & - & 168 \\
\hline Peltekoğlu 1993 & $x$ & - & 25 & $\begin{array}{l}\text { USA } \\
\text { Turkey }\end{array}$ & $x$ & 8 & - & - & 201 \\
\hline Peltekoğlu 2009 & $x$ & $x$ & 52 & $\begin{array}{l}\text { USA, France, Ger- } \\
\text { many, England }\end{array}$ & $x$ & 8 & - & - & 619 \\
\hline Uysal 1998 & - & - & - & Turkey & - & 8 & - & - & 251 \\
\hline
\end{tabular}

4 The first and only work in Turkish language which analyzes the history of public relations in Turkey by defining historical periods is "Milestones in Turkish Public Relations History" (2013) by A. Banu Bıçakçı and Pelin Hürmeriç. The authors apply the history of public relations to Grunig and Hunt's public relations model and classified the years between 1920 and 2012 as antecedents, emergence and development. 


\begin{tabular}{|c|c|c|c|c|c|c|c|c|c|}
\hline Bülbül 2000 & $x$ & $x$ & 34 & $\begin{array}{l}\text { USA, } \\
\text { Europe (Only } \\
\text { Country names) } \\
\text { and Turkey }\end{array}$ & $x$ & 17 & $x$ & 6 & 247 \\
\hline $\begin{array}{l}\text { Çamdereli } \\
2000\end{array}$ & $x$ & $x$ & 8 & $\begin{array}{l}\text { USA, } \\
\text { Europe (Only } \\
\text { Country names) } \\
\text { and Turkey }\end{array}$ & $x$ & 2 & - & - & 147 \\
\hline $\begin{array}{l}\text { Sabuncuoğlu } \\
2001\end{array}$ & $x$ & & 2 & USA & $x$ & 1 & $x$ & 1 & 204 \\
\hline $\begin{array}{l}\text { Okay and Okay } \\
2002\end{array}$ & $x$ & $x$ & 24 & & $x$ & 19 & & & 715 \\
\hline Biber 2004 & $x$ & $x$ & 4 & USA & - & 2 & $x$ & 1 & 123 \\
\hline Geçikli 2008 & $x$ & - & 14 & $\begin{array}{l}\text { USA, } \\
\text { England and } \\
\text { Turkey }\end{array}$ & $x$ & 2 & $x$ & 1 & 342 \\
\hline Erdoğan 2008 & $x$ & $x$ & 142 & $\begin{array}{l}\text { USA, } \\
\text { Europe and } \\
\text { Turkey }\end{array}$ & $x$ & 89 & $x$ & 67 & 396 \\
\hline Kazancı 2009 & $x$ & $x$ & 107 & $\begin{array}{l}\text { USA, } \\
\text { Turkey }\end{array}$ & $x$ & 75 & $x$ & 35 & 477 \\
\hline Bilgin 2010 & $x$ & - & 12 & $\begin{array}{l}\text { USA, } \\
\text { Turkey }\end{array}$ & $x$ & 5 & - & - & 232 \\
\hline $\begin{array}{l}\text { Budak and Budak } \\
2010\end{array}$ & $x$ & $x$ & 35 & USA, France, Italy & $x$ & 4 & - & - & 392 \\
\hline $\begin{array}{l}\text { Aktaş Yamanoğlu } \\
\text { et al. } 2014\end{array}$ & $x$ & $x$ & 237 & Turkey & $x$ & 237 & - & - & 237 \\
\hline
\end{tabular}

New Developments in Historiography of Public Relations

As can be seen from the results set out in the Table 3, new approaches emerged through the end of the 2000s in public relations literature in Turkish. Since 2008, the focus began to shift towards the history of public relations and the new editions of the existing books included parts about the history of public relations (e.g. Erdoğan 2008; Kazancı 2009). Public relations activities in the Ottoman Empire, which was the antecedent of the Republic of Turkey, began to be handled within a separate section in the books.

Public relations in the Ottoman Empire first appeared in a separate section in a book based on documents and certain studies with Public Relations in Public and Private Sector (2009 -first edition, 1995) by Metin Kazancı. Kazancı, while introducing the newly added section to the $9^{\text {th }}$ edition of the book, criticizes the existing historiography:

"We know that we experience public relations since the time when the dichotomy of the ruler and the ruled, seller and the buyer emerged. Some studies trace the history of public relations to Alexander the Great, some 
to the Roman Empire. Every country and every era has its specific type of public relations, whether it is named so or not. The reader will, after analyzing the newly added part entitled "Public Relations in the Ottoman Empire", understand that the Ottomans had a public relations program. This program, though, was not named as such. But basically it is a public relations strategy and it very much resembles today's understanding when compared in terms of the aims" (2009: 5).

An important turning point in the history of Turkey is the Single Party Rule between 1923 and 1946, the era of the foundation and development of the Republic. As Taylor and Kent states, "All nation building campaigns include large communication components that are essentially public relations campaigns" (2006: 347). The public relations campaigns used in the process of nation building in this era are generally not regarded as public relations campaigns since they are not "planned and systematic"; so they are instead named as propaganda. The public relations campaigns in the era have not been analyzed in detail in a book format yet, but they still constituted the main topic of an article entitled "A Neglected Area in Turkey in Terms of Public Relations: The Single-Party Period and the Public Relations Activities" (Karaaslan Şanlı 2013). This article focuses on the institutions established by the newly founded Republic to persuade and convince the people.

The last development in the history of public relations in Turkey is a book entitled History of Public Relations in Turkey: The Era of Institutionalization 19601980 (Aktaş Yamanoğlu et al. 2013). This book is the first in the public relations literature in Turkish in that it bears the statement of public relations history in its title. The book narrates the story of the development of public relations in Turkey between 1960 and 1980, which is generally accepted in almost all the books on public relations but never analyzed in detail, based on the narratives of the leading figures in the field by using oral history methods. The fact that the historical development, which constitutes the focal point of hegemonic public relations narratives, is finally analyzed in a book form is pleasing and saddening at the same time, as 40-45 years passed since the emergence of the events analyzed.

\section{Discussion and Conclusion}

"Yet there are other voices and experiences of public relations in Europe and elsewhere that developed separately from the US model" (Watson 2013: 206).

As underlined by the critical public relations approaches, the close relationship between culture and public relations has increasingly become an area of critical exploration in many parts of the world. In this regard, developed European countries such as England, Germany, France and Asian countries with different experiences of modernization such as China and Japan focus on history of public relations specific to the conditions of their country. 
As attempted to be presented by this study, the main problem of the historiography of public relations in Turkish is the lack of different and various approaches to the history of public relations within the public relations literature. This deficiency, or rather absence, does not result from a critical stance or perspective, but from the difficulties of going beyond the dominant paradigm. Nevertheless, efforts motivating the studies on the history of public relations encourage scholars in the field of public relations.

The calls of leading scholars for novelty in the historiography of public relations in Turkey especially in the past few years, and the reaction shown by emerging scholars constitute a great chance for the future of the literature of public relations in Turkish. Together with the limited number of new studies on the history of public relations in Turkey, a different perspective on the history of public relations emerged. The following may be stated about the contributions that the newly-emerging studies on the history of public relations can achieve in the field:

- There are a lot of definitions of public relations. It is clear that these definitions emerged as a result of certain historical processes when the use of public relations varied. The study of the history of each country's public relations will pave the way for new definitions of public relations thereby leading to new ways of understanding.

- New information to be unveiled through new perspectives with regard to the history of public relations will help the development of the professional reputation of public relations. The practice of public relations, which does not have much meaning for the common people as with many other terms of foreign origin, and which is mainly perceived negatively, will have a more realistic content together with the historical pattern included in the field.

- Different interpretations of the history of public relations and the incentives in this regard will help with the solution of problems between the state and the public which have been prevalent for many years.

The history of public relations in Turkey is still an untrodden path, with many written and visual sources waiting to be discovered. The studies on the history of public relations specific to the history of the country will be strengthened by offering new courses in this field, encouraging interdisciplinary studies and increasing the number of publications. 


\section{References}

AKTASS YAMANOĞLU Melike, GENÇTÜRK HIZAL G. Sanem and ÖZDEMIR B. Pınar (2013), Türkiye'de Halkla Illişkiler Tarihi: Kurumsallaşma Yılları 1960-1980, Ankara, De Ki Yayınevi.

ASNA M. Alâeddin (1967), Halkla illişkiler Ders Notları 1967-1968, Ankara, Siyasal Bilgiler Fakültesi Basın ve Yayın Yüksek Okulu.

ASNA M. Alâeddin (1997), Hi... Public Relations... P.R. Dünden Bugüne Bir Sanat-Meslek Öyküsü, İstanbul, Sabah Kitapları.

BIÇAKÇI A. Banu and HÜRMERiç Pelin (2013), "Milestones in Turkish Public Relations History", Public Relations Review, 39(2), pp. 91-100.

BiBER Ayhan (2004), Halkla Illişkilerde Teorik Bir Çerçeve, Ankara, Vadi Yayınları.

BiLGiN Lale (2010), Olumlu Bir Imaj Yaratmak Halkla ilişkiler, İstanbul, Kum Saati Yayınları.

BUDAK Gönül, BUDAK Gülay (2010), Imaj Mühendisliği Vizyonundan Halkla iliş̧kiler, İzmir, Barış Yayınları.

BÜLBÜL Rıdvan (2000), Halkla ilişkiler ve Tanıtım, Ankara, Nobel Yayınları.

ÇAMDERELi Mete (2000), Ana Çizgileriyle Halkla ilişkiler, Konya, Çizgi Kitabevi Yayınları.

DERINGiL Selim (2007), Simgeden Millete II. Abdülhamit'den Mustafa Kemal'e Devlet ve Millet, İstanbul, İletişim Yayınları.

ERDOĞAN İrfan (2008), Teoride ve Pratikte Halkla ilişskiler, Ankara, Erk Yayınları. ERTEKiN Yücel (1995), Halkla ilişskiler, Ankara, Türkiye ve Orta Doğu Amme İdaresi Enstitüsü Yayınları.

GEÇiKLi Fatma (2008), Hakla Iliş̧kiler ve Iletişim, İstanbul, Beta Yayınevi.

ipşiRLi Mehmet (1991), "Osmanlılarda Cuma Selamlığı: Halk-Hükümdar Münasebetleri Açısından Önemi", Prof. Bekir Kütükoğlu'na Armağan, İstanbul, İstanbul Üniversitesi Edebiyat Fakültesi Yayınevi, pp. 459-471.

KADIBEŞEGiL M. Salim (1986), Halkla Ilişkilerde Temel IIlkeler, İzmir, Tükelmat A. Ş.

KARAASLAN ŞANLI Halise (2013), "Türkiye'de Halkla İlişkiler Tarihi Açısından İhmal Edilmiş Bir Alan: Tek Parti Dönemi ve Halkla iliş̧kiler Faaliyetleri", Halkla ilişskilerin Kazancı, Melike Aktaş Yamanoğlu and B. Pınar Özdemir (eds.), Ankara, De Ki Basım Yayın, pp. 243-260.

KAZANCI Metin (2009), Kamuda ve Özel Kesimde Halkla Ilişsiler, Ankara, Turhan Kitabevi. 
LAMME M. Opdycke and RUSSEL K. Miller (2010), "Removing the Spin: Toward a New Theory of Public Relations History", Journalism and Communication Monographs 11, pp. 280-362.

MARDiN Betül (1988), "Halkla Illişkilerin ABD'de Gelişimi ve Avrupa'ya Girişi”, Halkla iliş̧kiler Sempozyumu-87, Ankara, Ankara Üniversitesi Basın-Yayın Yüksekokulu, Türkiye ve Ortadoğu Amme İdaresi Enstitüsü Yayınları.

OKAY Ayla and OKAY Aydemir (2002), Halkla ilişkiler Kavram, Strateji ve Uygulamaları, İstanbul, DER Yayınları.

PEARSON Ron (1990), "Perspectives on Public Relations History", Public Relations Review, 16(3), pp. 27-38.

PELTEKOĞLU Filiz Balta (1993), Halkla ilişkilere Giriş, İstanbul, Marmara Üniversitesi Yayınları.

PELTEKOĞLU Filiz Balta (2009), Halkla Iliş̧kiler Nedir?, İstanbul, Beta Basım A.Ş. SABUNCUOĞLU Zeyyat (2001), Işletmelerde Halkla Illişkiler, Bursa, Ezgi Kitabevi Yayınları.

TAYLOR Maureen and KENT Michael L. (2006), "Public Relations Theory and Practice in Nation Building", Public Relations Theory II, C.H. Botan and V. Hazleton (eds.), Mahwah, NJ, Lawrence Eribaum Associates, pp. 341-359.

WATSON Tom (2013), "Let's Get Dangerous: A Review of Current Public Relations Historical Scholarship", Halkla ilişkilerin Kazancı, Melike Aktaş Yamanoğlu and B. Pınar Özdemir (eds.), Ankara, De Ki Basım Yayın, pp. 201-216.

WATSON Tom (ed.) (2014), Middle Eastern and African Perspectives on the Development of Public Relations, London, Palgrave Pivot.

TORTOP Nuri (1973), Halkla iliş̧kiler, Ankara İktisadi ve Ticari Bilimler Akademisi Yayınları No: 55, Ankara, Emel Matbaacılık.

UYSAL Birkan (1998), Siyaset Yönetim Halkla ilişkiler, Ankara, Türkiye ve Orta Doğu Amme İdaresi Enstitüsü Yayınları. 